\title{
Inquérito sorológico para detecção de anticorpos de Toxoplasma gondii em caprinos (Capra hircus) criados nos municípios de Gravataí e Viamão, região da Grande Porto Alegre, Rio Grande do Sul, Brasil*
}

\author{
KAREN PRAETZEL MACIEL
}

Flávio Antonio Pacheco de Araújo (Orientador - UFRGS)

Banca: Carlos Marcos Barcellos de Oliveira (UFRGS), Silvia Maria Spalding (LACEN), Neusa Saltiel Stobbe (UFRGS)

\begin{abstract}
A toxoplasmose é uma das enfermidades parasitárias mais difundidas entre as transmissíveis. Novos aspectos parecem justificar o reaparecimento da questão da toxoplasmose, uma vez que esta vem sendo diagnosticada em um número crescente de pacientes com imunossupressão devida a varias causas tais como doenças malignas, transplantes de órgãos e principalmente, a Síndrome da Imunodeficiência Adquirida (SIDA). Mais de 50\% da população humana mundial acha-se infectada pelo Toxoplasma gondii com variações determinadas por fatores climáticos, sócio-econômicos, tipo de contato com animais domésticos e costumes alimentares relacionados ao consumo de carnes. O T. gondii é um protozoário que infecta praticamente todas as espécies animais. A caprinocultura exercida no Estado representa $0,4 \%$ de sua atividade pecuária total. O objetivo deste trabalho foi avaliar o papel desempenhado pela espécie caprina na transmissão do T. gondii. A amostragem foi estratificada por idade e gênero. Foram analisadas 360 amostras de soros caprinos através das técnicas da Hemaglutinação Indireta (HAI) e Imunofluorescência Indireta (IFI). Os resultados obtidos através da HAI estimam uma freqüência de 19,4\% (70 animais) de soropositividade e pela IFI de 30,0\% (108), o que representa índices elevados. Em relação à HAI, na variável gênero, foi observada uma freqüência de 9,44\% (34) de soropositividade para os machos e 10,0\% (36) para as fêmeas, enquanto que na variável idade, os resultados demonstram frequiências de 3,05\% (29) para os jovens e 11,38 (410 para os adultos. No que tange à IFI, a variável gênero demonstrou uma frequiência de $14,44 \%$ (52) de soropositivos para os machos e 15,56\% (56) para as fêmeas. Na variável idade, através desta mesma técnica, observou-se uma freqüência de soropositividade de 13,06\% (47) para jovens e de 16,94\% (61) para indivíduos adultos.ao compararem-se as duas técnicas os dados obtidos revelam uma associação significativa entre elas, com um índice de co-positividade para a HAI de 78,6\% e de co-negatividade de81,7\%. O índice Kappa, utilizado para medir o grau de concordância entre as duas técnicas, foi igual a $0,5 \%$ que evidencia um grau de concordância moderado entre elas, recomendando, desta forma, o uso cauteloso da HAI na espécie caprina. Os dados obtidos nos permitem concluir que os caprinos criados na região estudada podem ser fonte de transmissão de $T$. gondii para os seres humanos.
\end{abstract}

Descritores: Toxoplasma gondii, caprinos, IFI, HAI, inquérito sorológico. 


\title{
Serological evaluation of antibodies of Toxoplasma gondii in goats bred on Gravataí and Viamão counties, Great Porto Alegre, state of Rio Grande do Sul, Brazil ${ }^{* *}$
}

\author{
KAREN PRAETZEL MACIEL
}

Flávio Antonio Pacheco de Araújo (Adviser - UFRGS)

Committee: Carlos Marcos Barcellos de Oliveira (UFRGS), Silvia Maria Spalding (LACEN), Neusa Saltiel Stobbe (UFRGS)

Toxoplasmosis is one of the most widespread parasite infections among transmitted diseases. New aspects seem to justify the resurgence of Toxoplasmosis, since the disease has been diagnosed in a increased number of patients with suppressed immune system diseases related to various causes such as malign diseases, organ transplants, and particularly in those Acquired Immune Deficiency Syndrome (AIDS). Over 50\% of world's human population is infected with Toxoplasma gondii with variations established by climatic and socio-economic factors, type of contact with domestical animals, particularly cats, and eating habits related to meat consuption. The $T$. gondii is a protozoan that infects almost all animal species. Goat farming is a practiced activity in the State, representing $0.4 \%$ of its total livestock production. The aim of this work is to evaluate the role of goat species in T. gondii transmission. The sampling was stratified by age and gender. Three hundred sixty (360) goat sera samples were tested by Indirect Hemagglutination technique (IHA) and Indirect Immunofluorescence test (IIF). The obtained results showed that 19.4\% (70) of sera samples was positive to IHA and $30.0 \%$ (108) was 'positive to IIF, which represents a high level. Results of IHA associated to the variable gender showed $9.44 \%$ (34) sera positivity frequency for male goats and $10.0 \%$ (36) for females, whereas the results associated to the variable age showed frequencies of $3.05 \%$ (29) for young goats and $11.38 \%$ (41) for adults. The results determined by IIF related to the variable gender showed a frequency of $14.44 \%$ (52) positivity for males and $15.56 \%$ (56) for females. Using this same technique to evaluate the variable age, it was noted a soropositivity frequencyof $13.06 \%$ (47) for young goats and 16.94 (61) for the adults. The two techniques used in the research were compared, and the obtainned data showed a significant association between them, with a co-positivity rate with IHA of $78.6 \%$ and co-negativity of $81.7 \%$. The Kappa index used to measure the agreement among the two techniques was $0.5 \%$ showing a moderate agreement level among the techniques, therefore recommending cautions use in of IHA in the goats. The obtained data allowed us to conclude that the goats that are raised in the studied area may be considered a source of $T$. gondii to humans.

Key words: Toxoplasma gondii, goats, IFI, HAI, serological evaluation.

*"Master’s Thesis \#378 (Field: Parasitology). 63p. Graduate Program in Veterinary Sciences, Faculdade de Veterinária, Universidade Federal do Rio Grande do Sul (UFRGS), Porto Alegre/Brazil. CORRESPONDENCE: K.P. Maciel [kpraetzel@ terra.com.br]. 